Revue bibliographique pour le domaine irano-aryen

Volume 37-38-39 | 2018

Comptes rendus des publications de 2014-2016

\title{
Barbara Roggema (ed.). Communal Identity and Self- Portrayal in the Worlds of Eastern Christianity, 300-1500
}

Florence Jullien

\section{(2) OpenEdition}

1 Journals

\section{Édition électronique}

URL : http://journals.openedition.org/abstractairanica/44895

DOI : 10.4000/abstractairanica.44895

ISBN : 1961-960X

ISSN : 1961-960X

Éditeur :

CNRS (UMR 7528 Mondes iraniens et indiens), Éditions de l'IFRI

Référence électronique

Florence Jullien, « Barbara Roggema (ed.). Communal Identity and Self-Portrayal in the Worlds of Eastern Christianity, 300-1500», Abstracta Iranica [En ligne], Volume 37-38-39 | 2018, document 26, mis en ligne le 30 décembre 2018, consulté le 28 septembre 2020. URL : http://journals.openedition.org/ abstractairanica/44895 ; DOI : https://doi.org/10.4000/abstractairanica.44895

Ce document a été généré automatiquement le 28 septembre 2020.

Tous droits réservés 


\title{
Barbara Roggema (ed.). Communal Identity and Self-Portrayal in the Worlds of Eastern Christianity, 300-1500
}

\author{
Florence Jullien
}

\section{RÉFÉRENCE}

Barbara Roggema (ed.). Communal Identity and Self-Portrayal in the Worlds of Eastern Christianity, 300-1500. Farnham : Ashgate, 2014, 450 p. ISBN 978-0-7546-6891-6. (The Worlds of Eastern Christianity 300-1500, 14)

1 Comme le souligne l'éditrice de ce volume dans sa partie introductive, ce n'est qu'assez récemment que les chercheurs se sont attachés à l'étude des modalités d'affirmation identitaire des communautés chrétiennes orientales de l'Égypte jusqu'à l'Oxus, contrairement à l'histoire des débats et des polémiques en matière de doctrine. Cet aspect est cependant essentiel pour comprendre le positionnement de ces chrétiens du Proche et Moyen-Orient face aux changements culturels régionaux, et en réponse aussi à la domination étrangère. Cet ouvrage rassemble quinze contributions de chercheurs reconnus dans leur discipline sur la thématique de l'auto-définition des chrétiens orientaux, depuis la vallée du Nil jusqu'en Asie centrale (communautés copte, syriaque, arabe, arménienne et géorgienne) : perception de leur propre identité et représentation de l'autre, élaboration des traditions communautaires (par la recherche de racines bibliques notamment), ancrage linguistique, rôle de la doctrine dans la formation de la communauté et son affirmation face aux autres religions en particulier l'islam.

2 L'ouvrage comporte quatre parties précédées d'une bibliographie substantielle de référence sur la thématique donnée en introduction. La première réunit des réflexions diachroniques sur la formation des identités communes au sein du christianisme oriental copte, syriaque (M. G. Morony, « History and identity in the Syrian churches »), arabe et arménien. La seconde est consacrée à la question des doctrines et des débats 
identitaires plus spécialement dans l'Église syro-orientale, regroupant 3 articles, l'un sur le courant antiochien (Adam M. Schor, "Theodoret on the 'school of Antioch'. A network approach »), l'autre sur le mouvement d'autonomisation doctrinale de l'Église d'Orient au $V^{\mathrm{e}}$ siècle (W. Hage, «The Church 'of the East'. Ecclesiastical independence and ecclesiastical unity in the 5th century »), un dernier sur le statut de Nestorius dans l'Église syro-orientale (Karl Pinggéra, "Nestorius in the 'Nestorian' Church. Shedding light on the self-understanding of the Apostolic Church of the East»). La troisième partie a trait aux thèmes du langage et de l'ethnicité comme facteur identitaire dans l'Égypte byzantine, en milieu syriaque oriental (Adam H. Becker, «The ancient Near East in the late antique Near East. Syriac Christian appropriation of the Biblical past »; Winfried Boeder, «Identity and universality. Vernacular and written language in the lands of the ancient Christian East »), en Syrie-Palestine, en Arménie. La dernière partie a pour objet les confrontations inter-communautaires et les représentations en interne ; signalons une intéressante contribution de Jürgen Tubach sur la communauté chrétienne de Merw à l'époque sassanide («Boundary making and self-assertion in a multi-cultural environment. The Christian community of Merw, a metropolis on the Silk Road, in the late Sasanian period »). Un utile index achève cet ouvrage qui offre de nombreuses pistes en perspectives croisées.

\section{AUTEURS}

\section{FLORENCE JULLIEN}

CNRS, Mondes iranien et indien, Paris 